\title{
The Allocation of the Burden of Proof in Marine Fire Damage Cases
}

When cargo is damaged or destroyed in a fire at sea, the owner of the cargo (the shipper) must overcome two statutory exemption provisions in order to recover damages from the owner of the vessel (the carrier). The Limitation of Shipowners' Liability Act ${ }^{1}$ (the "Limitation Act") and the Carriage of Goods by Sea Act" ("COGSA"), respectively, exempt carriers from liability for fire damage unless the fire was caused by the carrier's "design or neglect"3 or "actual fault or privity." Not only must there be a negligent cause for the fire, but the negligence must be connected to the carrier ${ }^{5}$ before the shipper can recover. Although it is generally ac-

146 U.S.C. $\$ \S 181-188$ (1976).

246 U.S.C. $\$ \S 1300-1315$ (1976).

3 Limitation of Shipowners' Liability Act $\S 1$, 46 U.S.C. $\S 182$ (1976) (Loss by fire):

No owner of any vessel shall be liable to answer for or make good to any person any loss or damage, which may happen to any merchandise whatsoever, which shall be shipped, taken in, or put on board any such vessel, by reason or by means of any fire happening to or on board the vessel, unless such fire is caused by the design or neglect of such owner.

This exemption in the so-called "fire statute" extends only to the carrier. In maritime commerce, however, carriers often lease their vessels through a "charter-party" arrangement. Most charter-parties are for a specified time or a particular voyage; the carrier retains responsibility for selecting and supervising the crew and maintaining the vessel. These "time" or "voyage" lessees, or charterers, are not exempted from liability for fire damage by 46 U.S.C. $\S 182$. If the charterer takes on full responsibility for the vessel, the so-called "bareboat" charter (relatively rare in modern commerce), then the charterer is entitled to the exemption of the fire statute by $i d$. $\$ 186$. See G. Gilmore \& C. Black, The Law of ADMIRALTY 193-94 (2d ed. 1975).

- Carriage of Goods by Sea Act $\S 4,46$ U.S.C. $\$ 1304$ (1976) (uncontrollable causes of loss) ("(2) Neither the carrier nor the ship shall be responsible for loss or damage arising or resulting from ... (b) Fire, unless caused by the actual fault or privity of the carrier.").

COGSA applies to any bill of lading (contract of carriage) involving any vessel engaged in foreign trade carrying cargo by sea to or from ports of the United States. 46 U.S.C. $\$$ 1300 . Bills of lading arising out of the carriage of goods between United States ports may make COGSA applicable by express statement. 46 U.S.C. $\$ 1312$. COGSA only applies from "tackle to tackle," i.e., after loading and before the discharge of the goods. 46 U.S.C. § 1301(e). COGSA applies both to the owner of the vessel and to the charterer, regardless of the type of charter-party, cf. supra note 3; both are included in COGSA's definition of "carrier." 46 U.S.C. $\$ 1301(a)$. The fire statute was saved from repeal or modification. 46 U.S.C. $\S 1308$.

5 This phrase means the carrier must be involved personally in the "actual fault or privity" and "design or neglect." Without proof of this connection, the carrier will be exonerated from liability for fire damage. See Alfa Romeo, Inc. v. S.S. Torinita, 499 F. Supp. 
cepted that the shipper must prove the fire was caused by negligence ${ }^{6}$ there is considerable disagreement over which party should bear the burden of proving whether the negligence was connected to the carrier. ${ }^{7}$ Because catastrophic events at sea can cause the loss of most evidence of causation, burden of proof rules can have litigation determinative effects in admiralty cases. ${ }^{8}$ Burden of proof rules can also affect insurance and freight rates ${ }^{\theta}$ and shippers' choices of carriers. ${ }^{10}$

This comment addresses the allocation of the burden of proof in fire damage cases. After reviewing the historical development of shipowners' liability, the comment analyzes the interrelations of the various statutes that may be involved in fire damage litigation. Although the statutes offer little guidance for choosing a burden allocation rule, the alternatives available have strikingly different consequences for the internal coherence of the statutory scheme. The comment concludes that requiring the carrier to prove the absence of personal connection to the negligent cause of a fire better integrates the statutes defining the carrier's obligations to the shipper without diminishing the effect of the carrier's exemptions from liability for fire damage to cargo.

\section{General Maritime Law and Statutory Development of SHIPOWNERS' LIABILITY}

\section{A. General Maritime Law Liability}

Under general maritime law, the carrier insured the goods on

1272, 1282 (S.D.N.Y. 1980), aff'd mem., 659 F.2d 1057 (2d Cir. 1981); Hanson \& Orth, Inc. v. M/V Jalatarang, 450 F. Supp. 528, 540 (S.D. Ga. 1978); In re G.b.R.M.S. Caldas, 350 F. Supp. 566, 573 (E.D. Pa. 1972), aff'd mem., 485 F.2d 680 (3d Cir. 1973).

- See, e.g., In re Ta Chi Nav. (Panama) Corp., 677 F.2d 225, 229 (2d Cir. 1982); In re G.b.R.M.S. Caldas, 350 F. Supp. 566, 572 (E.D. Pa. 1972), aff'd mem., 485 F.2d 680 (3d Cir. 1973).

7 Compare Asbestos Corp. v. Compagnie de Navigation Fraissinet et Cyprien Fabre, 480 F.2d 669, 672-73 (2d Cir. 1973) (burden on shipper to show carrier's negligence) and Keene v. The Whistler, 14 F. Cas. 208, 208 (D. Cal. 1873) (No. 7645) (shipper must prove fire was caused by carrier's negligence) with Hasbro Indus. v. M.S. St. Constantine, 1980 Am. Mar. Cas. 1425, 1442 (D. Hawaii 1980) (carrier must prove it acted "without actual fault, privity, or neglect"), aff'd on other grounds, 698 F.2d 1008 (9th Cir. 1983) and In re G.b.R.M.S. Caldas, 350 F. Supp. 566, 572 (E.D. Pa. 1972) (burden on carrier to show no design or neglect), aff'd mem., 485 F.2d 680 (3d Cir. 1973).

Bee In re Marine Sulphur Queen, 460 F.2d 89, 98, 102 (2d Cir.), cert. denied, 409 U.S. 982 (1972); Federazione Italiana Dei Corsorzi Agrari v. Mandask Compania De Vapores, S.A., 388 F.2d 434, 436 (2d Cir.), cert. denied, 393 U.S. 828 (1968); States S.S. Co. v. United States, 259 F.2d 458, 460 (9th Cir. 1957); The Cleveco, 154 F.2d 605, 614 (6th Cir. 1946).

- See infra notes 135-38 and accompanying text.

${ }^{10}$ See infra notes 140-41 and accompanying text. 
its vessel. ${ }^{11}$ The carrier was held to a very high standard of prevoyage preparedness; a near absolute warranty of the vessel's seaworthiness ${ }^{12}$ was required. ${ }^{13}$ The carrier could escape liability for damaged cargo only if the damage was caused by an act of God, an act of a public enemy, the inherent vice of the cargo, or the fault of the shipper. ${ }^{14}$ Even if the damage was caused by one of these excepted perils, the carrier was still liable for his own negligence, the negligence of the master and crew of the vessel, and that of his other servants. ${ }^{15}$ There was no requirement that the negligence be personal to the carrier; virtually any negligence that caused cargo damage was imputed to the carrier, no matter who was responsible.

Although the liability rules under general maritime law were very different from those in force today, the allocation of the burdens of proof was substantially similar. The shipper first had to prove a prima facie case: that the cargo had been delivered to the carrier in good condition at the point of origin of the voyage, and that the carrier had failed to deliver the cargo in good condition at its destination. ${ }^{16}$ To escape liability, the carrier then had to prove the existence of an excepted peril. ${ }^{17}$ To overcome this defense, the

11 See New Jersey Steam Nav. Co. v. Merchants' Bank, 47 U.S. (6 How.) 344, 381 (1848); see also Consumers Import Co. v. Kabushiki Kaisha Kawasaki Zosenjo, 320 U.S. 249, 254 (1943); T. Carver, 1 Carriage by Sea 3-4 (11th ed. 1963).

12 Seaworthiness is a fundamental concept in maritime law. It forms the underpinnings of the carrier's duties under both general maritime law and later statutory enactments. See infra notes 34, 92. A precise definition of seaworthiness is not possible since it is a relative concept:

The requirement is that the vessel not only be staunch and strong, but also that she be fitted out with all proper equipment in good order, and with a sufficient and competent crew and complement of officers. But these requirements are relative to the voyage or service proposed. A ship that is in one or another of these respects unseaworthy for an Atlantic crossing in December may nevertheless be seaworthy for a coasting run to the South in the same season.

G. Grmore \& C. Black, supra note 3, at 65 (footnotes omitted). See also The Sagamore, 300 F. 701, 703 (2d Cir. 1924).

Is See Propeller Niagara v. Cordes, 62 U.S. (21 How.) 7, 23 (1859); see also Chamlee, The Absolute Warranty of Seaworthiness: A History and Comparative Study, 24 Mercen L. Rev. 519 (1974).

16 See G. Grimore \& C. Black, supra note 3, at 139-40; A. KnaUth, The American Law of OcEan Bills of Lading 116 (4th ed. 1953).

1s T. CARVER, supra note 11, at 18-19.

${ }^{16}$ See Transportation Co. v. Downer, 78 U.S. (11 Wall.) 129, 133 (1870) (in nonstatutory action, shipper established prima facie case by showing delivery in good condition and receipt of damaged cargo); Lawrence v. Minturn, 58 U.S. (17 How.) 100, 107 (1854) (in nonstatutory action, shipper established prima facie case by proof of delivery of goods at beginning of voyage, nonreceipt at their destination).

${ }^{17}$ See Propeller Niagara v. Cordes, 62 U.S. (21 How.) 7, 28 (1859) (in nonstatutory action, it was incumbent upon carrier to prove an excepted peril once cargo damage was 
shipper had to prove that the carrier had acted negligently or that negligence could be imputed to the carrier. ${ }^{18}$

\section{B. Limitation of Shipowners' Liability Act}

Common law nations were the last to allow carriers to abandon all proprietary interest in a vessel and thereby limit liability for cargo damage. ${ }^{19}$ In 1848 the Supreme Court reaffirmed the general maritime law principle that a carrier was the insurer of the cargo's safe delivery. ${ }^{20}$ This holding prompted Congress to enact the first national legislation limiting carrier liability, ${ }^{21}$ the Limitation of Shipowners' Liability Act, ${ }^{22}$ in 1851. The Limitation Act reduced the carrier's responsibility for cargo damage that occurred after the vessel had left the carrier's effective control. ${ }^{23}$ If the damage occurred "without the privity or knowledge" of the carrier, the carrier's liability was limited to the value of the vessel and the freight then pending. ${ }^{24}$

A separate exemption within the Limitation Act, known as the fire statute, ${ }^{25}$ exonerated the carrier from all liability for cargo

shown); Clark v. Barnwell, 53 U.S. (12 How.) 272, 280 (1851) (carrier must show damage was caused by excepted peril or express exception in bill of lading).

18 See Transportation Co. v. Downer, 78 U.S. (11 Wall.) 129, 133-35 (1870) (in nonstatutory action, it was reversible error for lower court to instruct jury that carrier had burden of showing absence of negligence); The Delhi, 7 F. Cas. 413, 414 (S.D.N.Y. 1870) (No. 3770) (in nonstatutory action, shipper must prove carrier negligence).

19 See The Rebecca, 20 F. Cas. 373, 380 (D. Me: 1831) (No. 11,619). Judge Ware's opinion in The Rebecca, in particular the discussion of the history of the limitation of liability, was cited with approval by the Supreme Court in Norwich Co. v. Wright, 80 U.S. (13 Wall.) 104, 116 (1871). Two states, Massachusetts and Maine, passed limitation acts early in the nineteenth century. See Donovan, The Origins and Development of Limitation of Shipowners' Liability, 53 Tut. L. Rev. 999, 1009 (1979).

10 New Jersey Steam Nav. Co. v. Merchants' Bank, 47 U.S. (6 How.) 344, $379-80$ (1848).

21 See H.R. Rep. No. 33, 31st Cong., 1st Sess. 1 (1850).

22 Ch. 43,9 Stat. 635 (1851) (current version at 46 U.S.C. $\$ \S 181-188$ (1976)).

23 See Craig v. Continental Ins. Co., 141 U.S. 638, 646-47 (1891).

24 Limitation of Shipowners' Liability Act $\$ 3,46$ U.S.C. $\S 183$ (1976).

(a) The liability of the owner of any vessel, whether American or foreign, for any embezzlement, loss, or destruction by any person of any property, goods, or merchandise shipped or put on board of such vessel, or for any loss, damage, or injury by collision, or for any act, matter, or thing, loss, damage, or forfeiture, done, occasioned, or incurred, without the privity or knowledge of such owner or owners, shall not ... exceed the amount or value of the interest of such owner in such vessel, and her freight then pending.

Id. "Freight then pending" has been held to mean the proceeds received by or due the carrier for that particular voyage. The Main v. Williams, 152 U.S. 122, 131-32 (1894).

${ }^{23}$ Limitation of Shipowners' Liability Act $\S 1$, 46 U.S.C. \& 182 (1976), quoted supra note 3. 
damage caused by fire. ${ }^{26}$ The separate exemption for fire was based on English law, ${ }^{27}$ but no substantive rationale for the separation is apparent from the legislative history. It may have been due to the extraordinary danger fire at sea has always posed to vessels. ${ }^{28}$

Allocation of the burden of proof under the fire statute was only alluded to in congressional debate on the Limitation Act. The comments suggest that Congress thought the burden of proving entitlement to the exemption would be on the carrier ${ }^{29}$ The first district court to deal with the question, however, held that the burden was on the shipper "to show that [the] fire was caused by the design or neglect of the [carrier],"30 and the vast majority of courts since have followed that first decision. ${ }^{31}$

${ }^{26}$ See Walker v. Transportation Co., 70 U.S. (3 Wall.) 150, 153 (1865).

27 The English statute in force in 1851 provided the carrier unconditional exoneration from liability for fire. 26 Geo. 3 , ch. $86, \S 2$ (1786). For the history of the early statutory development and the English influence on American law, see Donovan, supra note 19.

${ }^{28}$ "From earliest times fire has been one of the most terrifying perils of the sea which perhaps explains why a special exception has been made for it." W. TETtey, MarnNe Cargo Clarms 183 (2d ed. 1978). See also In re Liberty Shipping Corp., 509 F.2d 1249, 1250 (9th Cir. 1975).

29 Comments during Senate debate suggest that the carrier should not only prove that the damage was caused by fire, but also, as an initial matter, that the fire was not caused by carrier negligence. While discussing the effect that $\S 1$ of the Act, the fire statute, might have on parties' contracts, Senator Phelps of Vermont stated:

The exemption from responsibility should not be on account of certain actions, but the principle recognized by the bill should be this: that the utmost faithfulness and vigilance should be exacted from the carrier, and in case of loss he should be able to exempt himself from responsibility only by clearing himself of all culpability.

Cong. Globe, 31st Cong., 2d Sess. 719 (1851).

The concern expressed by Senator Phelps and others about the effect of the Limitation Act on parties' contracts was addressed by an amendment in the form of a proviso to $\S 1$ : "Provided, That nothing in this act contained shall prevent the parties from making such contracts as they please, extending or limiting the liabilities of ship-owners." Id. at 720. The proviso appeared in the statute as originally enacted, see Act of March 3,1851, ch. 43, § 1, 9 Stat. 635,635 (current version at 46 U.S.C. $\$ 182$ (1976)), but for no apparent reason was deleted in the 1874 revision, see U.S. REv. STAT. § 4282 (1875). Cf. Walker v. Transportation Co., 70 U.S. (3 Wall.) 150, 153-55 (1865) (for the stipulation in the contract to overcome a fire statute defense, the contract clause must be express).

so Keene v. The Whistler, 14 F. Cas. 208, 208 (D. Cal. 1873) (No. 7645). Before Keene, the fire statute had been construed in only two reported cases, Walker v. Transportation Co., 70 U.S. (3 Wall.) 150 (1865), and Dill v. The Bertram, 7 F. Cas. 698 (S.D.N.Y. 1857) (No. 3910).

The Supreme Court may have indicated a view contrary to the Keene rule through dictum in a case arising under the Limitation of Shipowners' Liability Act $\$ 3,46$ U.S.C. $\$$ 183 (1976). In Providence \& N.Y.S.S. Co. v. Hill Mfg. Co., 109 U.S. 578, 602 (1883), speaking of owners, the Court observed: "They may not be able, under the first section [46 U.S.C. $\S 182]$, to show that it happened without any neglect on their part . . . whilst they may be very confident of showing, under the third section [46 U.S.C. $\S 183$ ], that it happened without their privity or knowledge."

31 The great majority of cases have followed the Keene allocation. E.g., J. Howard 
Tension between shippers and carriers was not resolved by the passage of the Limitation Act. During the latter half of the nineteenth century both groups were dissatisfied with their legal relations under applicable law. ${ }^{32}$ Congress attempted to clarify the situation by passing the Harter Act $^{33}$ in 1893. The general principle underlying the Act was that if the carrier exercised due diligence to provide a seaworthy vessel, the carrier would be exempted from liability for damage arising from certain enumerated causes. ${ }^{34}$ The

Smith, Inc. v. S.S. Maranon, 501 F.2d 1275, 1277 (2d Cir.), cert. denied, 420 U.S. 975 (1974); Automobile Ins. Co. v. United Fruit Co., 224 F.2d 72, 75 (2d Cir.), cert. denied, 350 U.S. 885 (1955); Fidelity-Phenix Fire Ins. Co. v. Flota Mercante Del Estado, 205 F.2d 886, 887 (5th Cir.), cert. denied, 346 U.S. 915 (1953); American Tobacco Co. v. The Katingo Hadjipatera, 194 F.2d 449, 450 (2d Cir. 1951), cert. denied, 343 U.S. 978 (1952); Hoskyn \& Co. v. Silver Line Ltd., 143 F.2d 462, 463 (2d Cir.), cert. denied, 323 U.S. 767 (1944); The Older, 65 F.2d 359, 359-60 (2d Cir. 1933); The Salvore, 60 F.2d 683, 685 (2d Cir. 1932), cert. denied, 287 U.S. 653 (1932); Hanson \& Orth, Inc. v. M/V Jalatarang, 450 F. Supp. 528, 538 (S.D. Ga. 1978); The Sandgate Castle, 30 F. Supp. 344, 345 (S.D.N.Y. 1939); The Cabo Hatteras, 5 F. Supp. 725, 728 (S.D.N.Y. 1933). The first time the Keene rule was challenged was in Verbeeck v. Black Diamond S.S. Corp., 269 F.2d 68, 71 (2d Cir.), modified, 273 F.2d 61, 63 (2d Cir. 1959), cert. denied, 361 U.S. 934 (1960); see infra note 77 and accompanying text. 32 See G. Grmore \& C. BLAcK, supra note 3, at 142-43.

ss Ch. 105, 27 Stat. 445 (1893) (current version at 46 U.S.C. $\$ \S 190-196$ (1976)). The modern ambit of the statute is limited, although it still applies to the period of time before loading and after unloading the cargo, Carriage of Goods by Sea Act $\$ 12,46$ U.S.C. $\$ 1311$ (1976). The Harter Act also applies to domestic bills of lading and to on-deck cargo. See Blanchard Lumber Co. v. S.S. Anthony II, 259 F. Supp. 857 (S.D.N.Y. 1966).

34 The central concept of the Harter Act is contained in 46 U.S.C. $\S 192$ (1976):

If the owner of any vessel transporting merchandise or property to or from any port in the United States of America shall exercise due diligence to make the said vessel in all respects seaworthy and properly manned, equipped, and supplied, neither the vessel, her owner or owners, agent, or charterers, shall become or be held responsible for damage or loss resulting from faults or errors in navigation or in the management of said vessel nor shall [they] be held liable for losses arising from dangers of the sea or other navigable waters, acts of God, or public enemies, or the inherent defect, quality, or vice of the thing carried, or from insufficiency of package, or seizure under legal process, or for loss resulting from any act or omission of the shipper or owner of the goods, his agent or representative, or from saving or attempting to save life or property at sea, or from any deviation in rendering such service.

See also The Southwark, 191 U.S. 1, 8 (1903) ("The effect of this law is not to relieve the owner from the general duty of furnishing a seaworthy ship, but to limit his liability in certain particulars . ..."). This provision has been characterized as a compromise between shipper and carrier interests. See G. GILMORE \& C. BцACK, supra note 3, at 142-43. The absolute warranty of seaworthiness imposed by the general maritime law, see supra note 12 , was reduced to a duty to exercise due diligence to provide a seaworthy vessel. See G. GILMORE \& C. BlACK, supra note 3 , at 151 . The measure of due diligence, however, is broad. See International Nav. Co. v. Farr \& Bailey Mfg. Co., 181 U.S. 218, 225 (1901) ("the diligence required is diligence to make the ship in all respects seaworthy, and that . . . means due diligence on the part of all the owners' servants in the use of the [ship's] equipment before the commencement of the voyage" (emphasis in original)). See also The Wildcroft, 201 U.S. 378, 387 (1906); Erie \& St. Lawrence Corp. v. Barnes-Ames Co., 52 F.2d 217, 218-19 (W.D.N.Y. 1931); Villareal, The Concept of Due Diligence in Maritime Law, 2 J. MAR. L. \& 
Harter Act did not, however, address damage caused by fire. $.^{35} \mathrm{Al}-$ though the Harter Act was an innovative congressional response to problems in shipper-carrier relations, the Act did not relieve the pressure for greater legal clarification of responsibilities in maritime cargo law...$^{38}$

\section{The Hague Rules and COGSA}

Uncertainty and inconsistency among nations regarding the duties of shippers and carriers led to a series of international maritime law conferences in the 1890's and the early part of this century $^{37}$ that resulted in the Hague Rules. ${ }^{38}$ The rules are essentially based on the Harter Act principle. ${ }^{39}$ The Hague Rules, however, specifically include a fire liability exemption. ${ }^{40}$ There does not appear to have been any discussion of the allocation of the burden of proof under the fire exemption at the conferences drafting the Hague Rules. ${ }^{41}$ Although the United States signed the Hague Convention in $1925,{ }^{42}$ ratification of the Convention was not officially proclaimed until $1937 ;^{43}$ the rules were enacted as domestic legisla-

Coм. 763, 764 (1971).

ss 46 U.S.C. $\$ 196$ (1976) expressly saves the fire statute from modification or repeal.

se See A. KNAUTH, supra note 14, at 122-24.

s7 See generally id. at 124-27.

s8 International Convention for the Unification of Certain Rules Relating to Bills of Lading, opened for signature Aug. 25, 1924, 51 Stat. 233, T.S. No. 931, 120 L.N.T.S. 155 (U.S. ratification proclaimed Nov. 6, 1937); see generally A. KNAUTH, supra note 14, at 12631.

so G. GrLmore \& C. BlACK, supra note 3, at 143.

10 As originally drafted at the fifth session of the Hague conference the proposed fire exemption read: "Neither the carrier nor the ship shall be responsible for loss or damage arising or resulting from . . . [f]ire." REPORT OF THE DELEGATES OF THE U.S. TO THE INTERnational Conperence on Maritime Law, Fiftu Session 15 (1923) [hereinafter cited as 1923 RRPORT]. This would have resulted in carrier exoneration under all circumstances involving fire. The United States moved to add to art. IV(2)(b), the fire provision, the words "unless caused by the actual fault or privity of the carrier." This change was unanimously agreed to and adopted in the final version of the rules. Id. at 26. The source of the terms "actual fault or privity" probably was the English fire statute, Merchant Shipping Act, 1894, 57 \& 58 Vict., ch. 60, § 502. See Uniform Ocean Bills of Lading: Hearings on S. 1152 Before the House Comm. on Merchant Marine and Fisheries, 74th Cong., 2d Sess. 13 (1936) (memorandum of J.M. Johnson, Assistant Secretary of Commerce) [hereinafter cited as 1936 House Hearings]; Carriage of Goods by Sea: Hearing on S. 1152 Before the Senate Comm. on Commerce, 74th Cong., 1st Sess. 21 (1935) (memorandum of J.C. Peacock, director, U.S. Shipping Board Bureau) [hereinafter cited as Senate Hearing].

11 See 1923 REPORT, supra note 40, at 23-29 (mentioning discussion of most proposed rule changes but not of fire exemption change).

43 The convention was signed by the U.S. Ambassador at Brussels on June 23, 1925. 79 Cong. Rec. 4754 (1935).

ts See supra note 38 . 


\section{tion in 1936 in COGSA. ${ }^{44}$}

The only burden of proof issue discussed by Congress in enacting COGSA related to section $4(2)(q) .^{45}$ The section was drafted in response to a specific, and serious, problem. Beginning in the mid-nineteenth century, carriers regularly inserted numerous nonstatutory liability exception clauses in bills of lading. ${ }^{46}$ Courts normally upheld the validity of these exceptions ${ }^{47}$ and, applying the traditional burden of proof allocations, ${ }^{48}$ required the shipper to prove that the damage was caused by carrier negligence whenever an exception was shown. As the number and scope of these contractual exceptions grew, it became nearly impossible for shippers to recover damages from carriers, since shippers typically did not have access to evidence that would demonstrate carrier negligence. The burden allocation thus determined the outcome of many cargo

14 Pub. L. No. 74-521, 49 Stat. 1207 (1936) (codified at 46 U.S.C. $\$ \$ 1300-1315$ (1976)). COGSA has been called a congressional reaction to a Supreme Court decision considered adverse to carrier interests, May v. Hamburg-Amerikanische Packetfahrt A.G., 290 U.S. 333 (1933) (The Isis) (no exoneration under the Harter Act for shipowner who negligently fails to provide a seaworthy vessel, even if unseaworthiness was not related to the excepted cause of damage). See A. KNAUTH, supra note 14, at 129. See also 1936 House Hearings, supra note 40, at 11-12; Senate Hearing, supra note 40, at 19 ("This construction results in the imposition upon carriers of a liability which is more onerous than that imposed by the law of any other country.").

1546 U.S.C. § 1304(2)(q) (1976). See, e.g., 1936 House Hearings, supra note 40, at 4446, 68; Senate Hearing, supra note 40, at 33, 37, 47; H.R. RkP. No. 2218, 74th Cong., 2d Sess. 3, 6, 9 (1936); 79 Cong. Rsc. 13,341 (1935).

The fire exemption was not a central concern in the hearings, perhaps because of the perception that COGSA would work no fundamental change from the fire statute. See, e.g., 1936 House Hearings, supra note 40, at 63 (memorandum of American Steamship Owners' Association) ("[ $t]$ he bill will confer no advantage on the shipowner as respects losses by fire"). Further, although the enactment of the Hague Convention had been considered previously by Congress, there was virtually no discussion of the fire exemption in the earlier congressional considerations of the Convention. See generally Relating to the Carriage of Goods by Sea: Hearings on H.R. 3830 Before the House Comm. on the Merchant Marine and Fisheries, 71st Cong., 2d Sess. (1930); Relating to the Carriage of Goods by Sea: Hearings on H.R. 11447 Before the House Comm. on the Merchant Marine and Fisheries, 68th Cong., 2d Sess. (1925); Relating to the Carriage of Goods by Sea: Hearings on H.R. 14166 Before the House Comm. on the Merchant Marine and Fisheries, 67th Cong., 4th Sess. (1923); H.R. Rep. No. 1620, 68th Cong., 2d Sess. (1925).

16 See G. Gimore \& C. BLACK, supra note 3, at 141-42; see also Caterpillar Overseas, S.A. v. S.S. Expeditor, 318 F.2d 720, 722 (2d Cir.), cert. denied, 375 U.S. 942 (1963); Comment, Cargo Damage at Sea: The Ship's Liability, 27 TEx. L. REv. 525, 528 (1949).

47 See Clark v. Barnwell, 53 U.S. (12 How.) 272, 280 (1851). United States courts, however, held that a contractual liability exception could not exempt the carrier from liability for the negligence of his servants. See, e.g., Compania de Navigacion La Flecha v. Braver, 168 U.S. 104, 118-19 (1897); The Willdomino, 300 F. 5, 9 (3d Cir. 1924), aff'd sub nom. S.S. Willdomino v. Citro Chem. Co., 272 U.S. 718 (1927). British courts had taken the opposite position. See In re Missouri S.S. Co., 42 Ch. D. 321, 329 (1889).

18 See supra note 18 and accompanying text. 


\section{damage suits. ${ }^{40}$}

COGSA dealt with this problem in three ways. First, there are sixteen exemptions from carrier liability specifically listed in section $4(2)(a)-(p) .{ }^{80}$ Section $4(2)(q)$ then sets out a general liability exemption for "[a]ny other cause arising without the actual fault and privity of the carrier and without the fault or neglect of the agents or servants of the carrier."51 This was intended to eliminate the need for contractual exception clauses. ${ }^{52}$ Second, section $4(2)(q)$ provided that for any exemption not enumerated in section $4(2)(a)-(p)$, the burden of proof would fall on the carrier, rather than on the shipper, to show that the damage was not caused by carrier negligence. ${ }^{53}$ Finally, COGSA declared all contractual exception clauses that negated or lessened the statutory protections to be "null and void and of no effect."

\section{The Current Statutory Context for Fire Damage Cases}

The trial of a fire damage action is complicated by the uncer-. tain interplay of the statutes set out above. The Limitation Act, ${ }^{, 55}$. the fire statute, ${ }^{56}$ the Harter Act, ${ }^{57}$ and COGSA ${ }^{58}$ all are currently

19 $C f$. the following report:

Serious losses by pilferage, for instance, were prevalent during and after the World War, resulting in the refusal of underwriters to insure more than 75 percent of the risk against pilferage. It is sufficient to say that, under a Hague Rules bill of lading, full cover is now obtainable, inasmuch as the carrier, under the rules, is required to prove that the pilferage was not caused by his agents or servants, or through their negligence. 1936 House Hearings, supra note 40, at 46 (document prepared by Bank of America); see also id. at 26, 42, 61, 75-76; Senate Hearing, supra note 40, at 45, 48-49; Note, The Carriage of Goods by Sea Act, 23 VA. L. REv. 590, 595 (1937).

so 46 U.S.C. \& $1304(2)(\mathrm{a})$-(p) (1976). This list includes the fire exemption at $\S$ 1304(2)(b).

s1 Id. $\S 1304(2)(\mathrm{q})$.

62 H.R. Rep. No. 2218, 74th Cong., 2d Sess. 6-9 (1936). See also 1936 House Hearings, supra note 40, at 41, 100; Senate Hearing, supra note 40, at 44, 48, 73.

ss "[T] $]$ he burden of proof shall be on the person claiming the benefit of this exception to show that neither the actual fault or privity of the carrier nor the fault or neglect of the agents or servants of the carrier contributed to the loss or damage." Carriage of Goods by Sea Act § 4(2)(q), 46 U.S.C. § 1304(2)(q) (1976). See also sources cited supra note 52.

s4 46 U.S.C. $\$ 1303(8)$ (1976):

(8) Any clause, covenant, or agreement in a contract of carriage relieving the carrier or the ship from liability for loss or damage to or in connection with the goods, arising from negligence, fault, or failure in the duties and obligations provided in this section, or lessening such liability otherwise than as provided in this chapter, shall be null and void and of no effect.

ss 46 U.S.C. $\S \S 181-188$ (1976). See supra notes 21-24 and accompanying text.

se Limitation of Shipowners' Liability Act § 1, 46 U.S.C. § 182 (1976). See supra notes 25-28 and accompanying text.

s7 46 U.S.C. $\$ \S 190-196$ (1976). See supra notes 33-35 and accompanying text.

s8 46 U.S.C. $\$ \S 1300-1315$ (1976). See supra notes $38-44$ and accompanying text. 
in force. ${ }^{59}$ An equal, or greater, source of difficulty are the undefined interrelations between significant provisions within COGSA, in particular those between the fire exemption ${ }^{60}$ and the carrier's duty to provide a seaworthy vessel, ${ }^{61}$ and between the fire exemption and the specific burden allocation of section $4(2)(q){ }^{62}$ Judicial construction of the various statutes as they bear on the burden allocation in fire damage cases is sparse. This part examines these different statutes, as construed by the courts, looking in particular at their implications for allocation of the burden of proof in fire damage cases.

\section{A. COGSA Fire Exemption and the Fire Statute}

The fire statute in the 1851 Limitation Act, which was explicitly saved from repeal by the Harter Act ${ }^{63}$ and by COGSA, ${ }^{64}$ relieves the carrier of liability for cargo damage due to fire "unless such fire is caused by the design or neglect of such [carrier]." COGSA, however, contains a fire exemption of its own that relieves the carrier of liability for cargo damage due to fire "unless caused by the actual fault or privity of the carrier."6s There was some concern expressed in the congressional hearings on COGSA that the fire statute and the COGSA exemption might be interpreted differently by the courts because of the different language. In the end, it was decided that the terms were substantially equivalent; the lan-

89 Although no change in this statutory scheme appears imminent, the United Nations and other international organizations have been working in recent years to modify the legal relations between carriers and shippers. See Basnayake, Introduction: Origins of the 1978 Hamburg Rules, 27 AM. J. Comp. L. 353 (1979). A 1978 United Nations Convention, known as the Hamburg Rules, United Nations Convention on the Carriage of Goods by Sea, March 31, 1978, U.N. Doc. A/CONF. 89, reprinted in M. Cohen, A. SANn, B. Chase, N. GoldEN \& J. Grieder, 6 BenEdict on Admiralty 1-32.2. (7th ed. 1981) [hereinafter cited as 6 BBNBDICT], significantly expands the scope of carrier liability. See 6 BENEDICT, supra, at 1-35; Hellawell, Allocation of Risk Between Cargo Owner and Carrier, 27 AM. J. Comp. L. 357, 362-63 (1979); Note, The Hamburg Rules Fault Concept and Common Carrier Liability Under U.S. Law, 19 VA. J. INT'L L. 433, 444-46 (1979). Although the United States was a signatory to the Convention, prospects for its enactment as domestic legislation are dim. See Moore, The Hamburg Rules, 10 J. Mar. L. \& CoM. 1, 11 (1978); Comment, Risk of Loss in Shipping Under the Hamburg Rules, 10 DEN. J. INT'L L. \& PoL'y 568, 575 (1981).

so Carriage of Goods by Sea Act $\$ 4(2)(b), 46$ U.S.C. $\$ 1304(2)(b)(1976)$.

1 Id. $\& 3(1), 46$ U.S.C. $\S 1303(1)$ (1976).

62 Id. $\S 4(2)(q), 46$ U.S.C. $\S 1304(2)(q)(1976)$. See supra notes $45-53$ and accompanying text.

os See supra note 35.

- Carriage of Goods by Sea Act § 8, 46 U.S.C. $\$ 1308$ (1976).

es Limitation of Shipowners' Liability Act § 1, 46 U.S.C. $\$ 182$ (1976).

se Carriage of Goods by Sea Act $\S 4(2)(b), 46$ U.S.C. $\S 1304$ (2)(b) (1976). 
guage of the Hague Rules was retained in COGSA in the interest of international uniformity. ${ }^{67}$ Courts have treated the exemptions as identical. ${ }^{68}$ The allocation of the burden of proof articulated under the fire statute over a century ago-shipper must show the fire was caused by carrier design or neglect to overcome the exemption $^{68}$ - has enjoyed continued, largely unquestioned, popularity under COGSA.

\section{B. Section 3 of the Limitation Act}

Section 3 of the Limitation Act limits the carrier's liability to the value of the ship for loss or damage caused other than by fire, so long as the loss or damage occurred "without the privity or knowledge" of the carrier. ${ }^{70}$ The Supreme Court has placed the burden on the carrier to prove the loss occurred without his "privity or knowledge" in order to qualify for this limitation. ${ }^{11}$

It was once suggested that the standard of "privity or knowledge" differed from the fire statute's requirement that the loss not be due to the carrier's "design or neglect."72 More recent cases have treated the two standards as essentially equivalent; denial of exemption under the fire statute would require denial of limitation under section $3 .^{73}$ It is not uncommon for the same case to involve both statutes, ${ }^{74}$ and it might therefore seem sensible to have the same burden of proof allocation for the two equivalent provisions. ${ }^{75}$ It also appears fair superficially to require the carrier to

${ }^{67}$ See 1936 House Hearings, supra note 40, at 13, 141; Senate Hearing, supra note 40, at 60 .

se Se, e.g., In re Ta Chi Nav. (Panama) Corp., 677 F.2d 225, 228 (2d Cir. 1982); In re Liberty Shipping Corp., 509 F.2d 1249, 1251 (9th Cir. 1975).

See supra notes 30-31 and accompanying text.

70 46 U.S.C. $\S 183$ (1976). See generally supra notes 22-24 and accompanying text.

71 Coryell v. Phipps, 317 U.S. 406, 409-10 (1943).

${ }^{72}$ See Providence \& N.Y.S.S. Co. v. Hill Mfg. Co., 109 U.S. 578, 602 (1883); Hines v. Butler, 278 F. 877, 880 (4th Cir. 1921). See also G. GLMore \& C. BLAck, supra note 3, at 879.

${ }^{7 s}$ See, e.g., Great Atl. \& Pac. Tea Co. v. Brasileiro, 159 F.2d 661, 664 (2d Cir.), cert. denied, 331 U.S. 836 (1947); In re G.b.R.M.S. Caldas, 350 F. Supp. 566, 572 (E.D. Pa. 1972), aff'd mem., 485 F.2d 680 (3d Cir. 1973); see also G. Grmore \& C. BlAck, supra note 3 , at 879 .

${ }^{74}$ See, e.g., In re Ta Chi Nav. (Panama) Corp., 677 F.2d 225, 226 (2d Cir. 1982) (dealing with "petition of shipowner for exoneration from or limitation of liability for cargo damage claims resulting from a shipboard explosion and fire"); China Union Lines, Ltd. v. A.O. Andersen \& Co., 364 F.2d 769 (5th Cir. 1966) (involving both a collision and a fire).

${ }^{36}$ The notion of symmetry in the law formed the basis for Gilmore \& Black's position:

There is no reason why the allocation of the burden of proof should be different in

Fire Statute cases from the universally accepted allocation in Limitation Act cases . . . It may be that the use of the term "neglect" in the Fire Statute led to 
make at least as great a showing to obtain exoneration under the fire statute as to obtain the lesser benefit of the limitation section. Nevertheless, only one case has found the burden allocation under the fire statute to match the allocation for section 3 of the Limitation Act, ${ }^{78}$ and then only in dicta, based on questionable authority. ${ }^{77}$ Most of the decided cases are to the contrary, although none has analyzed the apparent conflict with section $3{ }^{78}$

\section{COGSA Section $4(2)(q)$}

COGSA section 4(2)(a)-(p) exempts carriers from liability for loss or damage arising from sixteen causes. ${ }^{79}$ COGSA section 4(2)(q) also exempts carriers from liability for loss or damage arising from "any other cause arising without the actual fault or privity of the carrier." ${ }^{80}$ The statute says nothing about the burden of proof for the exemptions listed in section 4(2)(a)-(p); it does, however, specify that the burden is on the carrier to prove there is no "actual fault or privity" to obtain the benefit of section $4(2)(q) .^{81}$ At least one court has read the explicit burden allocation in section $4(2)(q)$ as implying the opposite allocation for the exemptions in

judicial confusion: just as the plaintiff in a tort case bears the burden of proving the defendant's "negligence," so (it may have seemed to follow) the claimant in a Fire Statute case must bear the burden of proving the owner's "neglect."

... [T]

Fire Statute cases should be the same as in the Limitation Act cases: burden on the claimant to show negligence or fault; burden on the owner to show that the fire was not "caused by [his] design or neglect."

G. GLMORE \& C. BLACK, supra note 3, at 896.

76 In re G.b.R.M.S. Caldas, 350 F. Supp. 566, 572 (E.D. Pa. 1972), aff'd mem., 485 F.2d 678, 680 (3d Cir. 1973).

${ }^{77}$ Id. The court first cited Coryell v. Phipps, 317 U.S. 406, 409-10 (1943), which is distinguishable on the law, since Coryell was decided under 46 U.S.C. $\$ 183$ (1976), and on the facts, since Coryell did not involve a shipper-carrier dispute over fire damage. The court also relied on Verbeeck v. Black Diamond S.S. Corp., 269 F.2d 68, 71 (2d Cir. 1959). The opinion is of dubious precedential value. The court, per Clark, C.J., had stated: "Once negligence has been shown the burden of proof of coming within the exemption from liability of the Fire Statute . . . is on the owner." Id. at 71. Six weeks later, the carrier's petition for rehearing was granted. Verbeeck v. Black Diamond S.S. Corp., 273 F.2d 61 (2d Cir. 1959), cert. denied, 361 U.S. 934 (1960). The cause was remanded for a specific finding as to whether the owner was personally negligent, including whether the negligent actions of his agents could be imputed to him. Judge Moore's opinion (over a dissent by Chief Judge Clark) is, at best, an ambiguous repudiation of the earlier holding. Id. at 63.

78 See supra notes 30-31 and accompanying text.

70 46 U.S.C. $\S 1304(2)(a)$-(p) (1976). This list includes the fire exemption, id. $\S$ 1304(2)(b).

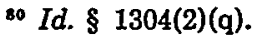

sI. 
section $4(2)(a)-(p) .^{82}$

However appealing this reading may be at first glance, there is no support for it in the legislative history of this section, nor does it hold up on closer examination of the specific exemptions in section 4(2)(a)-(p). The burden allocation in section 4(2)(q) was calculated to remedy a specific harm, namely, the abuse of nonstatutory exception clauses in bills of lading; ${ }^{83}$ it was not designed to create a backward looking burden of proof rule that would inform the rest of the statute.

The exemptions specifically listed in section 4(2) are independent of one another and of section $4(2)(q)$; they are not logically interconnected, nor are they of a homogeneous quality. The exemptions are derived from general maritime law, ${ }^{84}$ the Limitation Act, ${ }^{85}$ and the Harter Act; $;^{86}$ some were entirely new to American law. ${ }^{87}$ The courts that have applied these exemptions in cargo damage cases have not allocated the burdens of proof uniformly for all exemptions, but have fit the allocation to the purposes and characteristics of each exception. ${ }^{88}$ There appears to be no basis

82 To hold that when a carrier has shown that the loss arose as a consequence of restraint of princes, $\S 4(2)(\mathrm{g})$, it still has the burden of negating any other fault or neglect of its agents or servants would be to read the qualification of (q) into (a)-(p), although Congress did not put it there.

Lekas \& Drivas, Inc. v. Goulandris, 306 F.2d 426, 432 (2d Cir. 1962). Cf. In re Ta Chi Nav. (Panama) Corp., 677 F.2d 225, 229 (2d Cir. 1982) (court will not depart from prior precedent and place burden on carrier except where directed by statute).

ss See supra notes 45-54 and accompanying text.

st See supra notes 11-14 and accompanying text. These include the exemptions for damage caused by an act of God, 46 U.S.C. $\S 1304(2)(d)$ (1976), an act of public enemies, id. $\S 1304(2)(f)$, the fault of the shipper, id. $\$ 1304(2)(i)$, and an inherent defect in the cargo, id. $\S 1304(2)(\mathrm{m})$.

${ }^{88}$ For example, the fire exemption, 46 U.S.C. $\$ 1304(2)(b)$ (1976); cf. id. \& 182 (the fire statute).

${ }^{36}$ See supra notes 33-35 and accompanying text. These include the exemptions for damage by the fault of the master and crew of the ship, 46 U.S.C. $\S 1304(2)$ (a) (1976), perils of the sea, id. $\S 1304(2)$ (c), seizure at law, id. $\S 1304(2)(\mathrm{g})$, attempts to save life or property, id. $\S 1304(2)(l)$, and insufficient packing, id. $\S 1304(2)(n)$.

${ }_{87}$ These include the exemptions for act of war, 46 U.S.C. $\$ 1304(2)(e)(1976)$, restraint of princes, id. $\S 1304(2)(\mathrm{g})$, quarantine restrictions, id. $\S 1304(2)(\mathrm{h})$, strikes or lockouts, id. $\S 1304(2)(\mathrm{j})$, riots or commotions, id. $\S 1304(2)(\mathrm{k})$, insufficient marks, id. $\S 1304(2)(0)$, and latent defects, id. $\S 1304(2)(p)$.

${ }^{8 s}$ See, e.g., J. Gerber \& Co. v. S.S. Sabine Howaldt, 437 F.2d 580, 588-89 (2d Cir. 1971) (the burden of proof rules are altered under "perils of the seas" exception; ship has to establish freedom from negligence); Horn v. Cia de Navegacion Fruco, S.A., 404 F.2d 422, 435 (5th Cir. 1968) (carrier must show "inherent vice" of goods to receive statutory exculpation), cert. denied, 394 U.S. 943 (1969); The Daido Line v. Thomas P. Gonzalez, Corp., 299 F.2d 669, 671-72 (9th Cir. 1962) (in cases involving allegations of "inherent vice," burden of proof allocation is especially difficult; "clean" bill of lading is not enough to support shipper's prima facie case); American Tobacco Co. v. Goulandris, 281 F.2d 179, 181 (2d Cir. 1960) (the 
beyond legislative silence for determining the fire exemption burdens of proof according to the allocation in section $4(2)(q)$.

\section{The Carrier's Duty to Provide a Seaworthy Vessel}

The carrier's duty under COGSA to provide a seaworthy vessel $^{89}$ presents further complications regarding the burden of proof in fire damage cases. In every case where a shipper has recovered for fire damage to cargo, the court has found a prevoyage defect in the vessel that amounted to unseaworthiness. ${ }^{90}$ COGSA makes an explicit allocation of the burden of proof for seaworthiness, but not for the fire exemption.

COGSA adopts the general principle underlying the Harter Act $^{91}$ that the carrier is exempt from liability for cargo damage resulting from unseaworthiness only if the carrier exercised "due diligence" to provide a seaworthy vessel at the beginning of the voyage. ${ }^{22}$ The burden of proving the exercise of due diligence is placed

burden of showing freedom from "inherent vice" is on the shipper not the carrier); see also G. GILMORE \& C. BLACK, supra note 3, at 159-73.

so See infra notes 91-94 and accompanying text.

'0 See Sunkist Growers, Inc. v. Adelaide Shipping Lines, Ltd., 603 F.2d 1327 (9th Cir. 1979) (inadequate crew training, defective machinery), cert. denied, 444 U.S. 1012 (1980); In re Liberty Shipping Corp., 509 F.2d 1249 (9th Cir. 1975) (improper training of crew and equipment deficiencies); Asbestos Corp. v. Compagnie de Navigation Fraissinet et Cyprien Fabre, 480 F.2d 669 (2d Cir. 1973) (inadequate arrangement of fire fighting equipment); China Union Lines, Ltd. v. A.O. Andersen \& Co., 364 F.2d 769 (5th Cir. 1966) (unrepaired machinery, inadequate crew training), cert. denied, 386 U.S. 933 (1967); Verbeeck v. Black Diamond S.S. Corp., 269 F.2d 68 (2d Cir.), modified, 273 F.2d 61 (2d Cir. 1959) (negligent stowage of dangerous cargo), cert. denied, 361 U.S. 934 (1960); Isbrantsen Co. v. United States, 201 F.2d 281 (2d Cir. 1953) (improper stowage of dangerous cargo); Great Atl. \& Pac. Tea Co. v. Brasileiro, 159 F.2d 661 (2d Cir.) (lack of dispatch in bringing hazardous situation under control), cert. denied, 331 U.S. 836 (1947); United States v. Charbonnier, 45 F.2d 174 (4th Cir. 1930) (defective construction and incompetent officer); Williams S.S. Co. v. Wilbur, 9 F.2d 622 (9th Cir. 1925) (improper stowage), cert. denied, 271 U.S. 666 (1926); Hines v. Butler, 278 F. 877 (4th Cir. 1921) (improper conduct of crew), cert. denied, 257 U.S. 659 (1922); Hasbro Indus. v. M.S. St. Constantine, 1980 Am. Mar. Cas. 1425 (D. Hawaii 1980) (inadequate crew training, unrepaired machinery), aff'd on other grounds, 698 F.2d 1008 (9th Cir. 1983); Cerro Sales Corp. v. Atlantic Marine Enters., 403 F. Supp. 562 (S.D.N.Y. 1975) (undermanned, undertrained crew); Gesellschaft Für Getreidehandel A.G. v. S.S. Texas, 318 F. Supp. 599 (E.D. La. 1970) (allowing ship to leave port with unexplained smoking); The Sandgate Castle, 30 F. Supp. 344 (S.D.N.Y. 1939) (ship left port in a state of disrepair); The Doris Kellogg, 18 F. Supp. 159 (S.D.N.Y. 1937) (ship not in proper condition to carry dangerous cargo), aff'd mem., 94 F.2d 1015 (2d Cir. 1938); The Elizabeth Dantzler, 263 F. 596 (E.D. Va. 1920) (improper care of dangerous cargo).

9146 U.S.C. $\$ \S 190-196$ (1976). See supra notes 33-34 and accompanying text.

'2 Carriage of Goods by Sea Act § 3(1), 46 U.S.C. § 1303(1) (1976):

Responsibilities and liabilities of carrier and shipSeaworthiness (1) The carrier shall be bound, before and at the beginning of the voyage, to exercise due diligence to-

(a) Make the ship seaworthy; 
explicitly on the carrier. ${ }^{93}$ The carrier's duty to exercise due diligence to provide a seaworthy vessel is not delegable; any failure to exercise due diligence can be imputed to the carrier. ${ }^{94}$

The burden of proof for the COGSA fire exemption is not spelled out in the statute. Cases decided under the fire statute required the carrier to prove that the damage was caused by fire, and then required the shipper to prove that the fire was caused by the design or neglect of the carrier. ${ }^{95}$ Many courts have applied the same burden allocation to the COGSA fire exemption ${ }^{86}$ since the substantive terms of the statutes are equivalent.97 ${ }^{27}$ This allocation, however, would appear to be incompatible with the COGSA burden allocation for seaworthiness: COGSA requires the carrier to prove the exercise of due diligence to provide a seaworthy vessel, ${ }^{98}$

(b) Properly man, equip, and supply the ship;

(c) Make the holds, refrigerating and cooling chambers, and all other parts of the ship in which goods are carried, fit and safe for their reception, carriage, and preservation.

The carrier's liability for a failure of this duty is set out in Carriage of Goods by Sea Act $\S$ 4(1), 46 U.S.C. \& 1304(1) (1976):

Rights and immunities of carrier and shipUnseaworthiness (1) Neither the carrier nor the ship shall be liable for loss or damage arising or resulting from unseaworthiness unless caused by want of due diligence on the part of the carrier to make the ship seaworthy, and to secure that the ship is properly manned, equipped, and supplied, and to make the holds, refrigerating and cool chambers, and all other parts of the ship in which goods are carried fit and safe for their reception, carriage, in accordance with the provisions of paragraph (1) of section 1303 of this title. Whenever loss or damage has resulted from unseaworthiness, the burden of proving the exercise of due diligence shall be on the carrier or other persons claiming exemption under this section.

The definition of "seaworthiness" and "due diligence" in COGSA are the same as under the general maritime law, see supra note 12, and the Harter Act, see supra note 34. See Standard Oil Co. v. Anglo-Mexican Petroleum Corp., 112 F. Supp. 630, 636 (S.D.N.Y. 1955) ("The measure of due diligence under [COGSA] involved here is no different from that under the earlier Harter Act."); The Bill, 47 F. Supp. 969, 976 (D. Md. 1942), aff'd mem., 145 F.2d 470 (4th Cir. 1944) (measure of due diligence same under COGSA and the Harter Act). See also G. GLMore \& C. BLACK, supra note 3, at 150-51; Villareal, supra note 34, at 765.

is "Whenever loss or damage has resulted from unseaworthiness, the burden of proving the exercise of due diligence shall be on the carrier or other persons claiming exemption under this section." Carriage of Goods by Sea Act § 4(1), 46 U.S.C. § 1304(1) (1976).

o* See Federazione Italiana Dei Corsorzi Agrari v. Mandask Compania de Vapores, 388 F.2d 434, 438-39 (2d Cir.), cert. denied, 393 U.S. 828 (1968); Henson v. Fidelity \& Columbia Trust Co., 68 F.2d 144, 145 (6th Cir. 1933); Cerro Sales Corp. v. Atlantic Marine Enters., 403 F. Supp. 562, 567 (S.D.N.Y. 1975); B. Chase, M. Chynsky, J. Levine \& A. SANn, 2A BeneDICT on Admiralty 8-4 (7th ed. 1983) [hereinafter cited as 2A Benedict]; cf. G. GILMore \& C. BLACK, supra note 3 , at 152 (duty is nondelegable under British version of COGSA).

os See Keene v. The Whistler, 14 F. Cas. 208, 208 (D. Cal. 1873) (No. 7645). See also supra notes 30-31 and accompanying text.

See supra note 68 and accompanying text.

97 See supra notes 65-68 and accompanying text.

s3 See supra note 93 and accompanying text. 
but the fire statute allocation rule requires the shipper to prove that the damage was caused by the carrier's design or neglect, which amounts to proving the carrier's failure to provide a seaworthy vessel. ${ }^{98}$ The one provision puts the burden on the carrier to show a duty has been met, while the other would require the shipper to prove that virtually the same duty was neglected.

In Asbestos Corporation v. Compagnie de Navigation Fraissinet et Cyprien Fabre, ${ }^{100}$ the Second Circuit Court of Appeals noted that the traditional burden allocation for fire damage cases was at odds with the statutory burden to show the exercise of due diligence to provide a seaworthy vessel. ${ }^{101}$ Nevertheless, the court required the shipper to show the fire damage was caused by the carrier's actual fault or privity. The court declared that the fire exemption effectively overruled the statutory burden to show due diligence. ${ }^{102}$ Even if it were correct to frame the question as a choice between following the burden allocation under the seaworthiness section or giving effect to the fire exemption, it is not clear that the Second Circuit made the right choice. ${ }^{103}$ There is no support in the language of COGSA or its legislative history for making the fire exemption superior to the seaworthiness requirement. ${ }^{104}$ The court did not consider any allocation of the burden that would accommodate both statutory provisions in a fire damage case.

The Ninth Circuit, in contrast, has declared the COGSA seaworthiness requirement to be an "overriding obligation." 105 In Has"

- See supra note 30 and accompanying text.

100480 F.2d 669 (2d Cir. 1973).

101 Id. at 672.

103 "The burden of proof is on the carrier to show that he exercised due diligence. The fire exemption provisions merely shift this burden of proof to the shipper. If the carrier shows the damage was caused by fire, the shipper must prove that the carrier's negligence caused the damage." Id. at 672-73 (footnote omitted).

10s The burden allocation the Second Circuit assumed to be an integral part of the fire exemption may not have been a proper gloss on the statute as an original matter. What little evidence of congressional intent exists suggests that the burden of negating design or neglect under the fire statute should fall to the carrier. See supra note 29 and accompanying text. This mistake, if it was one, was well established by the time COGSA was enacted, however. See supra notes 30-31 and accompanying text.

104 See supra note 45. On the face of the statute, the two provisions appear to be of equal importance. See Carriage of Goods by Sea Act $\S \S 4(1), 4(2)(b), 46$ U.S.C. $\S \S 1304(1)$, 1304(2)(b) (1976).

${ }^{103}$ Sunkist Growers, Inc. v. Adelaide Shipping Lines, Ltd., 603 F.2d 1327, 1341 (9th Cir. 1979), cert. denied, 44 U.S. 1012 (1980). The apparent holding of Sunkist is that prior to receiving any fire exemption the carrier must prove the exercise of due diligence to provide a seaworthy vessel. Because of this interpretation, the Ninth Circuit did not specifically address the burden of proof question under either the fire statute or the COGSA fire exemption. Id. See also Hasbro Indus. v. M.S. St. Constantine, 698 F.2d 1008, 1010 (9th Cir. 1983). 
bro Industries v. M.S. St. Constantine ${ }^{106}$ a federal district court in Hawaii, following the Ninth Circuit position, placed the burden on the carrier to show the lack of "actual fault, privity, or neglect" once it had found that the vessel was unseaworthy. ${ }^{107}$ The Ninth Circuit's construction of seaworthiness has been subjected to considerable criticism. ${ }^{108}$ There is little more reason for declaring the seaworthiness requirement superior to the fire exemption than there is for declaring the fire exemption superior to the seaworthiness requirement. What remains to be attempted is a burden allocation that treats the two provisions equally.

\section{An Alternative Approach to Allocation of the Burden of Proof in Fire Damage Cases}

The burden of proof allocation developed under general maritime law and still generally followed for fire damage cases shifts the burden back and forth between shipper and carrier in a sort of ping-pong game. ${ }^{108}$ Following this pattern, it appears to fall to the shipper to prove that a fire was caused by the carrier's design or neglect, or actual fault or privity. ${ }^{110}$ This allocation is inconsistent

1061980 Am. Mar. Cas. 1425 (D. Hawaii 1980), aff'd on other grounds, 698 F.2d 1008 (9th Cir. 1983).

${ }^{107}$ Id. at 1442.

${ }^{108}$ For criticism of Sunkist see In re Ta Chi Nav. (Panama) Corp., 677 F.2d 225, 229 (2d Cir. 1982) ("The Sunkist court would read the language of subsection (q) into subsection (b), 'although Congress did not put it there.' " (quoting Lekas \& Drivas, Inc. v. Goulandris, 306 F.2d 426, 432 (2d Cir. 1962))); Calamari, The Eternal Conflict Between Cargo and Hull: The Fire Statute-A Shifting Scene, 55 ST. JoHN's L. REv. 417 (1981).

Before denying certiorari in Sunkist, the Supreme Court invited the Solicitor General to file a brief expressing the views of the United States. 444 U.S. 896 (1979). The Solicitor General's brief concluded that because of the facts in the case, the Ninth Circuit could have based its findings on established precedents. The Solicitor General recommended that the Court not take the case for review.

There are observations in the opinion of the court of appeals that, if taken out of context, could serve as the basis for novel admiralty doctrine. The court suggests at various points that the requirement of "due diligence" to make the ship seaworthy applies to master and crew as well as the owners and is an "overriding obligation" that must be fulfilled if the fire immunity provisions are to be invoked . . . . However, the implications of these views should await further clarification in light of the narrow basis for the court's actual holding. Moreover, the present case does not appear to be an appropriate vehicle for exploring issues of burden of proof in fire loss cases since the underlying facts establishing fault on the part of the owner were either "undisputed" ... or proven by "overwhelming evidence" . . . .

Brief for the United States as Amicus Curiae on Petition for a Writ of Certiorari to the United States Court of Appeals for the Ninth Circuit at 8 n.4, Adelaide Shipping Lines, Ltd. v. Sunkist Growers, Inc., 603 F.2d 1327 (9th Cir. 1979) (citations omitted).

${ }^{100}$ See supra notes 16-18 and accompanying text.

110 See supra notes 30-31 and accompanying text. 
with the burden allocation for nonfire damage actions under section 3 of the Limitation Act. ${ }^{111}$ A more significant problem is that this allocation threatens to vitiate the carrier's explicit statutory burden to prove the exercise of due diligence to provide a seaworthy vessel. ${ }^{112}$ This part analyzes the requirement of actual fault or privity, or design or neglect, and shows how a burden allocation of its component parts may better resolve the tension in the statutory scheme than does a unitary approach to the requirement.

\section{A. Control, Connection, and Seaworthiness}

The fire exemption is the only COGSA exemption that requires proof not only of overriding negligence but also of a direct connection of the negligence to the carrier. ${ }^{113}$ For a shipper to recover despite the fire exemption or the fire statute, the carrier must be found personally negligent. ${ }^{114}$ Personal negligence depends on two conditions. First, the negligence must have occurred or existed while the vessel was in the carrier's control, before and up to the beginning of the voyage. ${ }^{115}$ Second, the negligence must be

11 See supra notes 70-78 and accompanying text.

112 See supra notes 89-99 and accompanying text.

113 Hanson \& Orth, Inc. v. M/V Jalatarang, 450 F. Supp. 528, 538 (S.D. Ga. 1978). Of the seventeen liability exemptions in the Carriage of Goods by Sea Act $\$ 4(2)(a)-(q), 46$ U.S.C. $\$ 1304(2)(a)$-(q) (1976), the fire exemption, id. § 4(2)(b), 46 U.S.C. $\$ 1304(2)(b)$, is the only one with a purely personal aspect. See Approaches to Basic Policy Decisions Concerning Allocation of Risks Between the Cargo Owner and Carrier, U.N. Doc. A/CN.9/63/ Add. 1 (1972), reprinted in 1972 UNCITRAL Y.B. 287, 289, U.N. Doc. A/CN.9/SER. A/ Add. I (discussing burdens under the Hague Rules).

114 See Albina Engine \& Mach. Works, Inc. v. Hershey Chocolate Corp., 295 F.2d 619, 622 (9th Cir. 1961); Hartford Accident \& Indem. Co. v. Gulf Ref. Co., 230 F.2d 346, 355 (5th Cir.), cert. denied, 352 U.S. 832 (1956); Consumer's Import Co. v. Kawasaki Kisen Kabushiki Kaisha (The Venice Maru), 133 F.2d 781, 784 (2d Cir.), aff'd., 320 U.S. 249 (1943); The Older, 65 F.2d 359, 359 (2d Cir. 1933); see also 2A BENEDICT, supra note 94, at 14-32. Respondeat superior doctrines do not operate to deprive the carrier of the fire exemptions. Where the carrier is a corporation, the conduct of high managerial agents is considered "personal" to the carrier. See Spencer Kellogg \& Sons, Inc. v. Hicks, 285 U.S. 502, 511 (1932) (plant manager of corporation sufficiently high in corporation to create "privity or knowledge"); Craig v. Continental Ins. Co., 141 U.S. 638, 646 (1891) (when carrier is a corporation, the "privity or knowledge" must be that of the managing officers of the corporation); Walker v. Transportation Co., 70 U.S. (3 Wall.) 150, 153 (1865) (negligence of the master and crew cannot be imputed to the carrier); see also G. GlLMore \& C. Black, supra note 3, at 884-88 (discussing when a corporate shipowner is chargeable with privity or knowledge so as to defeat exemption).

115 See In re Liberty Shipping Corp., 509 F.2d 1249, 1252 (9th Cir. 1975) (incompetent crew and fire-fighting equipment); American Mail Line, Ltd. v. Tokyo Marine \& Fire Ins. Co., 270 F.2d 499, 501-02 (9th Cir. 1959) (fire occurred while ship was in port); Bank Line, Ltd. v. Porter, 25 F.2d 843, 846 (4th Cir. 1928) (carrier did not repair ship); Williams S.S. Co. v. Wilbur, 9 F.2d 622, 623 (9th Cir. 1925) (improper stowage), cert. denied, 271 U.S. 266 (1926); Cerro Sales Corp. v. Atlantic Marine Enters., 403 F. Supp. 562,567 (S.D.N.Y. 1975) 
such that the carrier himself or a managing agent of the carrier should have discovered and corrected the negligent condition, that is, the negligence must be connected, not just imputed, to the carrier. ${ }^{116}$ Without the presence of both carrier control and connection in a fire damage case, the carrier will be exempt from liability. ${ }^{117}$

The terms control and connection form the conceptual underpinnings of "design or neglect" and "actual fault or privity." The control issue reduces to a question of chronology: did the negligence leading to the fire occur before the voyage began? ${ }^{118}$ The facts relating to this question are typically indistinguishable from those going to the proof of negligence itself. ${ }^{119}$ The connection issue, on the other hand, involves identification of the individuals responsible-or who should have been responsible-for the negligence, which may be wholly unrelated to the facts showing the underlying negligence itself.

Analyzing the fire exemption in terms of control and connection presents a way to flesh out its relationship to the carrier's

(crew too small and inadequately trained); The Sandgate Castle, 30 F. Supp. 344, 345 (S.D.N.Y. 1939) (inadequately repaired ship); The Doris Kellogg, 18 F. Supp. 159, 166 (S.D.N.Y. 1937) (carrier allowed a fire hazard to exist on ship), aff'd mem., 94 F.2d 1015 (2d Cir. 1938); The Elizabeth Dantzler, 263 F. 596, 597 (E.D. Va. 1920) (fire occurred while ship was in port).

${ }_{116}$ See Asbestos Corp. v. Compagnie de Navigation Fraissinet et Cyprien Fabre, 480 F.2d 669, 670-72 (2d Cir. 1973) (carrier did not correct inadequately designed fire-fighting system); In re Isbrandtsen Co., 201 F.2d 281, 284 (2d Cir. 1953) (carrier's agent supervised negligent stowage of dangerous cargo); Great Atl. \& Pac. Tea Co. v. Brasileiro, 159 F.2d 661, 663-64 (2d Cir.) (carrier's agent did not take proper measures to control fire), cert. denied, 331 U.S. 836 (1947); United States v. Charbonnier, 45 F.2d 174, 176-77 (4th Cir. 1930) (carrier hired incompetent officer); Gesellschaft Fur Getreidehandel A.G. v. S.S. Texas, 318 F. Supp. 599, 600 (E.D. La. 1970) (carrier's agent allowed ship to leave port smoking).

117 See Earle \& Stoddart, Inc. v. Ellerman's Wilson Line, Ltd., 287 U.S. 420, 425-28 (1932) (although negligence occurred while the vessel was under carrier's control, the negligent act was done by a person whose conduct could not be imputed to the carrier).

${ }^{218}$ A provocative question is raised by the situation where the carrier is in communication with the vessel while at sea. See, e.g., The Cleveco, 154 F.2d 605 (6th Cir. 1946). Given the tremendous effective authority of the master while the vessel is at sea, the traditional doctrine ending the period of the carrier's control at the point the vessel is underway would appear to be a sensible rule. But see G. Grimore \& C. BLACK, supra note 3, at 894 (arguing that technological developments have "destroyed the factual assumption on which the older case law rested").

110 For a shipper to prove that a fire was caused by improper stowage, for example, would necessarily require proof that the negligence occurred while the vessel was under the carrier's control since cargo is stowed before the voyage begins. See Isbrandtsen v. United States, 201 F.2d 281, 284 (2d Cir. 1953). Similarly, proof that a fire was caused by an improperly trained crew member would necessarily coincide with a showing that the negligence-not properly manning the ship-occurred while the vessel was under the carrier's control. See Cerro Sales Corp. v. Atlantic Marine Enters., 403 F. Supp. 562, 567 (S.D.N.Y. 1975). 
statutory duty to exercise due diligence to provide a seaworthy vessel. ${ }^{120}$ The issue of control focuses attention on the period of time prior to the start of the voyage, as does the requirement of providing a seaworthy vessel. The connection issue focuses attention on the carrier's personal obligations, as does the duty to exercise due diligence to provide a seaworthy vessel. The correspondence helps explain the coincidence of shipper recovery for fire damage and facts showing unseaworthiness. ${ }^{121}$ If negligence leading to a fire occurred while the vessel was in the carrier's control before the start of the voyage and the negligence was connected to the carrier personally, the requirements for actual fault or privity and failure to exercise due diligence to provide a seaworthy vessel are both satisfied.

Despite the coincidence, there is not a perfect identity between the carrier's duty to exercise due diligence to provide a seaworthy vessel and the fire exemption's standard of actual fault or privity or design or neglect. The fire exemption can be overcome only if the carrier's high managerial agents are directly connected to the negligence that resulted in fire damage. ${ }^{122}$ The carrier's duty to exercise due diligence to provide a seaworthy ship is nondelegable; any failure to fulfill this duty can be imputed to the carrier, regardless of personal connection. ${ }^{123}$ Although any negligence that is directly connected to the carrier would suffice to prove want of due diligence to provide a seaworthy ship, not all acts or omissions attributable to the carrier under the seaworthiness requirement would satisfy the fire exemption's personal connection requirement. A fire exemption burden allocation may be shaped around this disparity that integrates the exemption with the carrier's statutory burden to prove due diligence.

\section{B. Allocation of the Connection Issue}

Once the requirement of actual fault or privity, or design or neglect, is broken into its component parts of control and connection, it becomes clear that it is the allocation of the connection issue that brings the traditional allocation in fire cases into conflict with the COGSA seaworthiness provision. If the burden falls to the shipper to prove carrier connection to the negligence that led to the fire damage, then the carrier will have escaped the statutory

\footnotetext{
120 See supra notes $91-98$ and accompanying text.

121 See supra note 90 and accompanying text.

112 See supra notes 5, 113-14, 116 and accompanying text.

${ }^{123}$ See supra note 94 and accompanying text.
} 
burden of proving the exercise of due diligence to provide a seaworthy vessel. If, however, the burden shifted to the carrier to prove the exercise of due diligence once the shipper proved the existence of negligence leading to the fire damage while the vessel was in the carrier's control, the personal aspect of the fire exemption would be effectively eliminated. The solution, suggested by the decision in Hasbro Industries, ${ }^{124}$ is to split the difference.

Both the seaworthiness requirement and the personal aspect of the fire exemption can be preserved if the burden is placed on the carrier to prove the exercise of due diligence only with regard to those persons whose conduct has traditionally been imputed to the carrier in fire damage and limitation cases: directors, managing agents, shoreside supervisors, and the like. ${ }^{125}$ The carrier would not have to prove the vessel was seaworthy in all respects, ${ }^{126}$ nor would it have to prove the exercise of due diligence by all personnel in its employ. ${ }^{127}$ The carrier would have the burden of proving the absence of a direct connection between the unseaworthiness that caused the fire damage and the carrier's high-level personnel. By limiting the reach of the due diligence requirement in this way, the statutory burden allocation is preserved without vitiating the personal aspect of the fire exemption. The tension between the fire exemption and the seaworthiness requirement is resolved without shunting either provision to an inferior position.

\section{Other Legal and Economic Consequences of Allocating the Connection Issue to the Carrier}

1. Connection and the Limitation Act. Placing the connection burden on the carrier in fire damage cases would bring the fire statute into harmony with the Supreme Court's burden of proof allocation for section 3 of the Limitation Act, covering nonfire damage actions. ${ }^{128}$ This allocation also would follow the trend in

124 See supra notes 106-07 and accompanying text.

${ }^{125}$ See The Pocone, 1946 Am. Mar. Cas. 821, 830-31 (E.D.N.Y. 1946), rev'd on other grounds sub nom. Great Atl. \& Pac. Tea Co. v. Brasileiro, 159 F.2d 661 (2d Cir.), cert. denied, 331 U.S. 836 (1947). See also supra note 116 and accompanying text.

${ }_{128}$ Thus the doctrine of The Isis, effectively repudiated by Congress with the passage of COGSA, see supra note 44, would not be revived. The unseaworthiness present would have to be the proximate cause of the fire or its damage. See The Sandgate Castle, $30 \mathrm{~F}$. Supp. 344, 345 (S.D.N.Y. 1939).

${ }^{127}$ This allocation would thus not be contrary to the Supreme Court's decision in Earle \& Stoddart, Inc. v. Ellerman's Wilson Line, Ltd., 287 U.S. 420 (1932). The chief engineer (a ship's officer) was negligent in that case, $i d$. at 424; his conduct would not be connected to the carrier under the proposed rule.

128 See supra note 71 and accompanying text. 
modern admiralty cases to interpret the Limitation Act strictly. ${ }^{129}$ The Limitation Act is viewed today as a nineteenth-century anachronism and courts have been more willing to deny limitation than were their predecessors of the last century. ${ }^{130}$

2. The British Rule. British precedents are well respected in American admiralty courts, largely due to our joint common law traditions. ${ }^{131}$ The British statutory scheme is similar to that of the United States, with the language of the respective COGSA fire exemptions being identical. ${ }^{132}$ The British have for many years allocated the burden on the connection issue to the carrier. ${ }^{133} \mathrm{~A}$ similar allocation under United States law would bring two important and closely related admiralty jurisdictions into conformity on this issue.

3. Cost Effects of Allocating the Connection Burden to the Carrier. The effects of a particular burden allocation rule on maritime commerce are necessarily uncertain and speculative. Carriers faced with a greater burden of proof before receiving exoneration from liability might take greater precautions resulting in a decrease in the number of fires on board vessels. This consideration is somewhat undercut by the interest the carrier already has in the prevention of fire: the preservation of the vessel. ${ }^{134}$ Allocation of

129 See, e.g., Continental Oil Co. v. Bonanza Corp., 677 F.2d 455, 466 (5th Cir. 1982); In re Barracuda Tanker Corp., 409 F.2d 1013, 1015 (2d Cir. 1969).

1so See, e.g., Maryland Casualty Co. v. Cushing, 347 U.S. 409, 437-38 (1954) (Black, J., dissenting) (4-1-4 decision); see also Donovan, supra note 19, at 1035-37; Springer, Amendments to the Federal Law Limiting the Liability of Shipowners, 11 ST. JoHn's L. REv. 14, 38-39 (1936); Thede, Statutory Limitations (Other Than Harter and COGSA) of Carrier's Liability to Cargo-Limitation of Liability and the Fire Statute, 45 TuL. L. REv. 959, 987 (1971); Comment, The Maritime Law Association's Proposed Statute on Shipowners' Limitation of Liability: A Practical Alternative to the IMCO Convention, 10 LAw AM. 839, 84445 (1978); Comment, Shipowners' Limitation of Liability-New Directions for an Old Doctrine, 16 Stan. L. REv. 370, 389 (1964).

13s See, e.g., Standard Oil Co. v. United States, 340 U.S. 54, 59 (1950); May v. Hamburg-Amerikanische Packetfahrt A.G., 290 U.S. 333, 352-54 (1933) (The Isis); Knott v. Botany Mills, 179 U.S. 69, 74 (1900); Horn v. Cia de Navegacion Fruco, S.A., 404 F.2d 422, 434 \& n.16 (5th Cir. 1968), cert. denied, 394 U.S. 943 (1969); The Hermosa, 57 F.2d 20, 2425 (9th Cir. 1932).

132 Carriage of Goods by Sea Act, 1924, 14 \& 15 Geo. 5, ch. 22, art. IV(2)(b).

123 The English rule on the connection issue is that the carrier must disprove "actual fault or privity." Lennard's Carrying Co. v. Asiatic Petroleum Co., 1915 A.C. 705, 715-16 (H.L. 1915); see also Northern Fishing Co. v. Eddom, [1960] 1 Lloyd's List L.R. 1, 11 (H.L. 1960); Patterson S.S., Ltd. v. Robin Hood Mills, Ltd., [1937] 58 Lloyd's List L.R. 33, 39 (P.C. 1937); Corporation of the Royal Exch. Assurance v. Kingsley Nav. Co., 1923 A.C. 235, 244-45 (P.C. 1923); T. Carver, supra note 11, at 213; W. TetLEY, supra note 28, at 185.

1st See Hellawell, supra note 59, at 365 n.20; see generally R. PoSNER, Economic ANALYSIS of LAW 78-79 (2d ed. 1977) (discussing the allocation of insurance risks in performance of contracts frustrated by fire). 
the connection issue to the carrier might also affect freight rates, most likely causing them to go up. ${ }^{135}$

The setting of freight rates is in part determined by the price the carrier has to pay for protection and indemnity insurance. ${ }^{136}$ Allocation of the connection issue to the carrier might lead to an increase in the carrier's insurance costs. Shippers also normally carry insurance on their cargo. By allowing a possibility of easier recovery against the carrier, the allocation of the connection issue to the carrier might cause a downward adjustment of cargo insurance rates. ${ }^{137}$ Shifting the burden of proof allocation between parties will not necessarily shift the costs exactly between carrier and shipper. Carrier and cargo insurance are typically underwritten at different places and may respond to market pressures differently. ${ }^{138}$

The role of the burden of proof rules in encouraging settlement and decreasing the costs of litigation should also be taken into consideration. Allocating the connection issue to the carrier might encourage carriers to settle in more cases, thereby reducing litigation costs. Conversely, allocating the connection issue to the shipper might prevent the prosecution of damage suits where the evidence was doubtful or nonexistent. In any event, establishment of a clear rule one way or the other would eliminate some costs involved in pursuing uncertain claims or defenses. ${ }^{138}$

Finally, it must be remembered that the Limitation Act and later congressional enactments were intended in part to advance the interests of United States carriers and to encourage capital in-

13s Many large international carriers are members of shipping conferences that set the rates for particular shipping routes. The participation of U.S. carriers in the conferences is exempt from antitrust laws. See 46 U.S.C. § 814 (1976); see also G. GLMore \& C. BLAck, supra note 3, at 990-95. The exact effect of a burden of proof rule on those freight rates is difficult to ascertain. See Approaches to Basic Policy Decisions Concerning Allocation of Risks Between the Cargo Owner and Carrier, supra note 113, at 295.

13e Most carriers are insured through protection and indemnity ("P\&I") clubs, mutual associations that insure against the carrier's liability for, among other risks, cargo damage. The dominant clubs are in Europe. See Selvig, The Hamburg Rules, the Hague Rules and Marine Insurance Practice, 12 J. MaR. L. \& CoM. 299, 311 (1981).

137 The cargo underwriting business has been characterized as highly competitive, a situation that could lead to lower premiums if the cargo underwriters have a greater ability to obtain payment for damages from the P\&I clubs. See Selvig, supra note 136, at 316.

${ }^{138}$ Unlike the carrier's P\&I coverage, cargo insurance is normally underwritten in the place of the origin of the goods. Thus marine insurance underwriting should be analyzed from the perspective that there are two different markets involved. See Selvig, supra note 136 , at 311.

138 See Posner \& Rosenfield, Impossibility and Related Doctrines in Contract Law: An Economic Analysis, in The Economics of Contract Law 136 (A. Kronman \& R. Posner eds. 1979). 
vestment in shipping. ${ }^{140}$ The traditional allocation rule might influence shippers to avoid shipping cargo on United States vessels. Conversely, allocating the connection issue to the carrier might encourage shippers to enter shipping contracts with United States carriers. Notwithstanding the traditional congressional interest in the American maritime industry, the United States is now more of a shipper than a carrier nation. ${ }^{141}$ The proposed allocation of the connection issue to the carrier is thus a better reflection of the current commercial status of United States shipping interests.

\section{Conclusion}

The fire statute and the COGSA fire exemption represent a unique benefit to the carrier. The traditional burden allocation requires the shipper to prove the connection of the carrier to the negligence involved in the fire. This rule is inconsistent with the burden allocation for nonfire Limitation Act cases and with the explicit statutory burden in COGSA requiring the carrier to show its exercise of due diligence to provide a seaworthy vessel. This comment recommends placing the burden on the shipper to prove the negligence involved in the fire and requiring the carrier to prove the absence of connection to that negligence. This rule would integrate the interpretation of all the statutes involved in fire damage litigation and tend to produce a more even balance in the allocation of the risks in a maritime venture.

James H. Hohenstein

140 See Cong. Globe, 31st Cong., 2d Sess. 332, 715 (1851); see also Norwich Co. v. Wright, 80 U.S. (13 Wall.) 104, 121 (1872); G. Grmore \& C. BLACK, supra note 3, at 818-19. The federal government is still very committed to assisting the shipping industry. See, e.g., The Merchant Marine Act of 1970, Pub. L. No. 91-469, 84 Stat. 1018 (codified in scattered sections of 5, 15, 33, 40 \& 46 U.S.C. (1976)); Consumers Import Co. v. Kabushiki Kaisha Kawasaki Zosenjo, 320 U.S. 249, 254-55 (1943); Norwich Co. v. Wright, 80 U.S. (13 Wall.) 104, 121 (1871); Automobile Ins. Co. v. United Fruit Co., 224 F.2d 72, 75 (2d Cir.), cert. denied, 350 U.S. 885 (1955); see generally G. Grumore \& C. BLAcK, supra note 3, at 963-82 (discussing the history of government activities designed to promote the welfare of the shipping industry).

${ }^{161}$ See Note, supra note 59 , at 440. 